\title{
IMAGE IN NON-ARTISTIC TEXT AS A FACTOR DEVELOPING READING STRATEGIES OF SECONDARY TECHNICAL SCHOOLS' PUPILS
}

\author{
a DANA VICHERKOVÁ, 'MARKÉTA ŠENKEŘÍKOVÁ, \\ 'DENISA LICHÁ \\ University of Ostrava, Faculty of Education, Department of \\ Education and Adult Education, Fráni Šrámka 3, Czech \\ Republic \\ email: ${ }^{a}$ dana.vicherkova@osu.cz \\ bmarketka.senkerikova@centrum.cz, 'denisa.licha@email.cz
}

This paper was written within the SGS project entitled "Factors influencing the level of reading strategies of pupils of secondary schools with technical specialization, OSU", registration number SGS01/PDF / 2020, carried out at the Faculty of Education at the University of Ostrava in 2020.

Abstract: The paper focuses on the current problem of factors influencing the reading of non-artistic texts and the development of reading strategies of pupils of secondary technical schools in the Moravian-Silesian Region of the Czech Republic. The paper aims to reflect, describe, analyse and evaluate which types of non-artistic texts, images, and depictions develop pupils' reading strategies. The text presents selected results of the quantitatively oriented questionnaire survey focusing on the identification of the relationship between the pupil's notion of a non-artistic text and course of work with the image as factors influencing their reading strategies. The partial goal of the pilot research is to point out the factors influencing student teachers at the Faculty of Education of the University of Ostrava in working with non-artistic text, an image in the text and their understanding.

Keywords: image in a non-artistic text, reading strategies, secondary technical schools' pupils, factors of text comprehension, student teacher.

\section{Introduction}

Image is a part of the reader's education, developing their communication, reading comprehension. By reading image information, we learn to think critically. An effective image decoding can be listed among the reading strategies developing reading and visual, digital literacy of individuals and the whole society.

\section{Working with image and text in retrospective}

Working with image belongs among illustrative methods with their primary characteristic being a fast transfer of information, knowledge, experience scales. The beginnings of cave paintings as a type of communication can be dated back to prehistoric times. Illustrations (paintings) on the walls of temples occurred in Ancient Egypt, which is also the cradle of book illustrations, documented, e.g. in the Book of the Dead. Klimeš (2015) points out the fact that the picture-writing cannot be understood as the first illustration since it does not allow to separate the text and image part. "Picture-writing was a means of communication" (Klimeš, 2015, pp. 25 - 26). Image interaction reflects the life of society in relation to the natural, cultural, industrial and educational laws. A few researchers were interested in the interweaving of character types, e.g. Lessing, who perceived "natural" features in the painting and "arbitrary" features in the literature. Jacobson (1993) claims that it is possible to analyse the iconic features in the syntactic structure of language (Jacobson \& Pomorska, 1993, p. 68). The principle of illustration is based on various scientific theories, e.g. philosophical, psychological, sensualistic, pedagogical. Sternberg (2009) explains that "it is characteristic for both media that neither of them contains all the features of the represented object, but there is always a certain selection from many features of it” (Sternberg, 2009, pp. 243 - 244). In contrast to non-artistic texts, we do not primarily encounter the form of pure character types in artistic texts and painting.

\subsection{Text and image in the process of education}

Maňák \& Švec (2003, p 76) pointed out the relationship between the concept of the cognitive process and the principle of illustration "which requires the teaching to be based on the demonstration of phenomena or their representation". Linhart (1982) states that "perception is both a basic process of cognition and a governing component of human activity in which human cognition has evolved and continues to develop" (Linhart, 1982, p. 151). Authors (Maňák \& Švec, 2003, p. 77) classified the illustration into four categories as starting points for school teaching based on sensory perception, thus "demonstration of real objects and phenomena, realistic depiction of real objects and phenomena, their intentionally altered depiction and apprehension of reality through diagrams, graphs, signs, symbols, abstract models, etc.". By respecting the authors' view, images and drawing can be classified into so-called pre-machine aids according to the developmental point of view. Representations are understood as schemes, realistic images, static and dynamic projections (Maňák \& Švec, 2003, p. 80). Images can be a part of tactile aids (e.g. maps, reliefs). Currently, we encounter educational visualisation not only in non-artistic texts, e.g. in professional texts (textbooks, encyclopaedias) but most frequently in the artistic texts (fiction). "The didactic (school) image is understood as a depiction of a phenomenon for use in the educational process, in various forms and modifications, regardless of its specific form of implementation." (Maňák \& Švec, 2003, p. 83).

When working with text, it is appropriate to gradually or visually analyse individual parts of the image, which leads to a comprehension of the image as a whole. When working with different kinds of written information, it is appropriate to proceed in the same way as we learn to think critically and strategically. Dondis (1984) enumerated the essential visual elements, including "point, line, shape, direction, toning, colour, structure, scale, movement" (Dondis, 1984, p. 39). Mailaret (1975) pointed out three levels of image perception allowing pupils to read the image gradually. The first level includes the simple recognition of the object when pupils, e.g. enumerate individual parts of the image, in the plane of impressions from the viewing of the image. In the next level, pupils describe, characterise the picture, explain what they consider to be more or less important by so-called visual reading. The third level reading the data contained in the image - is already a strategic manifestation of reading, with pupils "incorporating the information obtained from the image into the system of knowledge, which is further processed by cognitive operations" (Mailaret, 1975, p. 99). Image communication by graphic signs, symbols, schemes is, in the $21^{\text {st }}$ century, a manifestation of the communication of the so-called information age, when it is not possible to measure precisely how much new information was created at a given moment. New innovative languages, which we understand as communication, image sharing are emerging in technically oriented fields,. "The speech of images is closer to reality than verbal signs because the image brings a broader scope of the phenomenon, the information included in the image is more open and flexible than the language" (Maňák \& Švec, 2003, p. 84).

In the contemporary world, we learn to think visually in everyday situations and create a visual communication culture. We process information through schematisation. We capture primary or specific features "which, in reality, or realistic representation, are lost in the globality of the substantial and insignificant, typical and accidental" (Maňák \& Švec, 2003, p. 85). In modern educational resources, but also the texts of everyday life, we encounter the creation of mind maps (clustering), through which students recognise various relationships, deduce direct or distant connections, develop socalled reasoning, comparison, diagnosis, interpretation, reconstruction of knowledge, etc. Concept maps are currently a part of a diverse range of instructions. Working with the image supports the growth of creativity, technical thinking, entrepreneurship. Working with the image according to the valid curricular documents (FEP STVE, SEP) at the Czech technically focused secondary schools can be classified among tasks requiring more complex cognitive processes, e.g. independent creation of drawings, projects, tasks for practical application, tasks for discovering based on one's observations and 
considerations, tasks requiring the solution of problematic professionally-oriented situations, etc. Pictorial (non-verbal) and verbal text in teaching texts are a means of social communication in teaching. Working with images helps to rationalise pupils' thinking.

\section{Researches of Learning with image}

Verbal learning is a subject of research for more than 100 years. The research of "learning from visual material" is experiencing an increasing interest today. Mareš (1995) argues that "in developed countries, research is being developed into how one learns from visual material and how visual material should be designed to make learning easier for people." (Mareš, 1995, p. 318). Research interest is focused e.g. on the problem of processing of visual information in non-artistic text. Several research surveys are interested in models of simple coding of information (by analysing both image and letters and their further processing in the activisation of semantic memory and transfer to more abstract planes). Dual coding model considers a multidirectional information processing. Mareš (1995) comes up with the statement that in the process of image analysis, activation of nonverbal memory occurs simultaneously with the analysis of letters, sounds and with the transfer of their results to the verbal memory. The resulting concept thus possesses both verbal and non-verbal aspect. The sensoric-semantical model enriches the visual and written characteristics also by phonemic characteristic (Mareš, 1995, pp. 320 - 321). The result of the model of triple coding of information are "auditory logogen, visual logogen and pictogen, which pass into the cognitive system, which further processes them" (McLean - Thorne, 1994). In the levels of visual information communication, three levels (according to Mareš, 1995) can be distinguished: syntactic, semantic, pragmatic. Their functions e.g. decorative, representing, organising, interpreting, transforming can also be analysed in the didactically focused non-artistic texts. Mareš (1995) also draws attention to other functions of visual material, such as affective-motivational, function of attention concentration and cognitive-regulatory functions. Feming (1987), Rankin (1989) were also interested in possible approaches towards the diversity of functions of visual material. The research (Mareš, 1995) was focused on the relationship between psychodidactic and aesthetic functions of the visual material, e.g. scientific character of the illustration versus artistic metaphor, further to the "logic of the verbal expression of knowledge, the relationship between sign and symbol, the relationship between cognition and experience" (Mareš, 1995, p. 326). Klimeš (2015) who was interested in the relationship between text and illustration, states that the verbal text and its illustration "brings two different views, the result of which is the same meaning" (Klimeš, 2015, p. 103). The Trahorsch, Bláha, Janko (2018) research was focused on the problem of visuals in Geography textbooks and pointed out the terminological inaccuracy of the designation for the non - text - illustrative component of textbooks and also as well as the insufficient number of visuals in geography textbooks for the ISCED 1 age group. Research results pointed out the fact that "the quality of visuals can be problematic, as it can distort the visualised phenomenon or process or even cause misconceptions if the concept is inappropriately chosen "(Trahorsch, Bláha, Janko, 2018, p. 112). Park's (2012) research based on social constructivism and focused on the problem of using visualisation as a bridge to text understanding, the development of critical literacy, reading literacy. In a psychological research experiment, Daňková (2013) focused on the problem of applying the principle of illustration in the preparation of a psychology textbook. The results of this research confirmed that "active visualisation is necessary for good memorisation - own techniques of incorporating information into the already existing knowledge system" (Daňková, 2013, p. 41). Molnár, Tláskal (2012) researches suggest the decrease in the level of spatial imagination of pupils and point to a decline in pupils' competencies in the process of phenomena visualisation. They also emphasise the need to increase the level of reading and socalled visual speech as part of the language of a particular subculture. Flood, Heath, Lapp (2008) also researched pupils' visual literacy.

\subsection{Visual image, visual and reading literacy}

A visually literate person can work with the image in the text correctly and functionally. Fulková (2012) states that an image "is a visual or mental expression arising from a certain impulse, containing specific characteristics and requiring a certain interpretation" (Fulková, 2002, p. 12). Image visualisation in electronic and paper texting is a factor that contributes to the development of visual and reading literacy, i.e. reading and digital strategies as significant components of functional literacy. "Visual literacy is so far understood mainly as a way to defend against the manipulative social effects of visual communication, especially in the media and advertising." (Uhl Skřivancová, 2014, p. 89). Image visualisation in non-artistic texts has an interdisciplinary overlap.

\section{Research methodology}

The research was carried out within the project SGS01 / Pdf / 2020 at the Faculty of Education of the University of Ostrava focusing on factors influencing the quality of reading strategies of pupils of secondary technical schools in the MoravianSilesian Region of the Czech Republic. The research was executed in two phases. In the first stage, it was a quantitatively oriented research through a questionnaire focusing on the image in a non-artistic text as a factor developing the reading strategies of students of secondary technical schools. The research was carried out on a sample of 156 pupils of secondary technical schools aged 15 - 19 years (May - October 2020). The questionnaire contained 43 closed items. This paper includes eight items with their formulation being presented in selected research outputs with their descriptive and statistical processing. The study aims to point out the key statistically verified relationships between variables. The second phase of the research, executed by the semi-structured interview, focused on the identification of factors that influence student teachers at the Faculty of Education of the University of Ostrava when working with non-artistic text, an image in text and their comprehension.

4.1 Selected questions of the questionnaire research from the perspective of pupils

1. What is the relationship between the student's notion of choosing an interactive book (non-artistic text) for reading and the student's use of reading strategy, namely the search for only essential information in the text.

2. What is the relationship between the pupil's notion of preferring books (non-artistic text) with illustrative accompaniment and the pupil's use of reading strategy, namely the search for the context in the text.

3. What is the relationship between the pupil's notion of preferring books (non-artistic text) with illustrative accompaniment and the use of the reading strategy in asking questions when reading the text.

4. What is the relationship between the pupil's priority when choosing a book in terms of the design of its cover and the pupil's decision to purchase the book due to its aesthetic processing.

5. What is the relationship between the pupil's appreciation of the book in terms of non-traditional processing and the pupil's idea of selecting an interactive book (non-artistic text) to read.

\subsubsection{Selected hypotheses for the questionnaire research}

Hypothesis H1: Pupils who stated that they choose to read the so-called interactive book (as a non-artistic text), search for the essential information more frequently than pupils who answered that they do not select the so-called interactive books.

Hypothesis H2: Pupils who answered that they prefer books (non-artistic text) whose text is accompanied by illustrations, search the text for context more frequently than pupils, who 
stated that they do not prefer books whose text is accompanied by illustrations.

Hypothesis H3: Pupils who stated that they prefer books (nonartistic text) whose text is accompanied by illustrations pose questions more frequently while reading the text than pupils who answered that they do not prefer books whose text is accompanied by illustrations.

Hypothesis H4: Pupils who answered that they are influenced by the design of the book cover when selecting a book, bought the book more frequently due to its nice (aesthetic) processing than pupils who stated that they are not affected by the design of the book cover.

Hypothesis H5: Pupils who stated that they appreciate a nontraditional design of books more frequently select so-called interactive books than pupils who answered that they do not appreciate their non-traditional design of books.

\subsubsection{Selected results of the questionnaire research and their interpretation}

Question B8: Do you select so-called interactive books? (e.g. with an electronic pencil, or books with a task needed to be solved in order to continue)

This item found out (by choosing from two options) whether pupils select so-called interactive books to read. Research results suggest that $127(81.4 \%)$ respondents stated that they do not choose to read the so-called interactive book and 29 (18.6\%) respondents stated that they choose to read the socalled interactive book.

Question E2: Do you search only for only essential information in the text and ignore other (non-essential) information?

This item found out (by choosing from two options) whether the pupils search only for only relevant information in the text and whether they ignore other (non-essential) information. Eighty-two (52.6\%) respondents stated that they search only for essential information in the text and ignore other (nonessential) information and $74(47.4 \%)$ respondents stated that they do not search only for essential information and pay attention to the other.

Question B3: Do you prefer books with text accompanied by illustrations or photographs?

This item found out (by choosing from two options) whether pupils prefer books with text accompanied by illustrations or photographs. The results confirm that 95 (60.9\%) respondents stated that they prefer books with text accompanied by illustrations or photographs and 61 (39.1\%) respondents stated that they do not prefer books with text accompanied by illustrations or photographs.

Question E5: Do you search for context throughout reading? (Linking new information with what you already know)

This item found out (by choosing from two options) whether the pupils search for context in the text throughout reading. Research results show that 109 (69.6\%) respondents stated they search for the context throughout the reading the text and $47(30.1 \%)$ respondents stated that they do not search for a context throughout reading the text.

Respondents further stated that:

- 91 (58.3\%) are not influenced by the cover design when selecting the book. (question B1)

- $128(82.1 \%)$ never bought the book only for its well-made design. (question B2)

- $96(61.5 \%)$ appraise an original design of books. (question B5)

- $112(71.8 \%)$ do not pose auxiliary questions when reading. (question E7)
4.1.3 Results of processing selected hypotheses and their verification

The research did not confirm that:

- pupils who choose to read the so-called interactive book (as a non-artistic text) in the questionnaire survey, search for the essential information more frequently than pupils who do not select the so-called interactive books. (H1)

- pupils who prefer books (non-artistic text) with text accompanied by illustrations pose questions more frequently while reading the text than pupils who do not prefer books with text accompanied by illustrations. (H3)

- pupils who appreciate a non-traditional design of books more frequently select so-called interactive books than pupils who do not appreciate a non-traditional design of books. (H5)

The research confirmed that:

- pupils who prefer books (non-artistic text) with text accompanied by illustrations, search the text for context more frequently than pupils, who do not prefer books with text accompanied by illustrations. (H2)

Tab. 1: Observed and expected frequencies (H2)

\begin{tabular}{|c|c|c|c|}
\hline \multicolumn{4}{|c|}{ Pearson's chi-square $=4.041532$} \\
degree of freedom = 1 & significance $p=0.0443935$ \\
\hline Question B3 & $\begin{array}{c}\text { Question E5 } \\
\text { (yes) }\end{array}$ & $\begin{array}{c}\text { Question E5 } \\
\text { (no) }\end{array}$ & Line totals \\
\hline yes & $72(66.38)$ & $23(28.62)$ & 95 \\
\hline no & $37(42.62)$ & $24(18.38)$ & 61 \\
\hline
\end{tabular}

Pupils who are influenced by the design of the book cover when selecting a book, bought the book more frequently due to its nice (aesthetic) look than pupils who are not affected by the design of the book cover. (H4)

Tab. 2: Observed and expected frequencies (H4)

\begin{tabular}{|c|c|c|c|}
\hline \multicolumn{4}{|c|}{ Pearson's chi-square $=19.121939$} \\
degree of freedom = 1 & significance $p=1.22627 \mathrm{E}-05$ \\
\hline Question B1 & $\begin{array}{c}\text { Question B2 } \\
\text { (yes) }\end{array}$ & $\begin{array}{c}\text { Question B2 } \\
\text { (no) }\end{array}$ & Line totals \\
\hline yes & $22(11.67)$ & $43(53.33)$ & 65 \\
\hline no & $6(16.33)$ & $85(74.67)$ & 91 \\
\hline Column totals & 28 & 128 & 156 \\
\hline
\end{tabular}

4.2 Mixed design research survey through semi-structured interviews with pupils of teaching

Eleven students of primary school teacher training at the University of Ostrava in the fields of music education, art education, special education, Czech, pedagogy participated in the second part of the research (a pilot study). The interviews were conducted in October 2020. The interview consisted of a total of 45 items, with 28 being dichotomous and 17 open. Questionnaire items were classified into three categories labelled A, B, C (A: Content of images in non-artistic text, B: Perception of an image in the non-artistic text, $C$ : Learning through illustrated text). The aim of the semi-structured research interviews was to find out:

- what types of reading strategies student teachers use in the learning process when working with non-artistic text,

- the influence of the image in the non-artistic text on the learning (reading) process in the observed sample,

- popularity of teaching resources with different types of images (pictograms, photographs, illustrations),

- what types of illustrations in non-artistic text (teaching resources) student teachers distinguish, 
- the importance student teachers attribute to the image in the text as a factor influencing the comprehension of the text.

4.2.1 Selected results of a pilot research survey conducted by a semi-structured interview from the perspective of student teachers and their interpretation

In this paper, we present selected results of the pilot phase of research conducted by semi-structured interviews with student teachers at the University of Ostrava.

The research found that:

- $81.8 \%$ of respondents work with non-artistic texts, which include pictograms,

- $100 \%$ work with non-artistic texts, which include photographs,

- $81.8 \%$ of respondents perceive the importance of photography in the process of understanding the text,

- $63.6 \%$ of respondents use books (textbooks, teaching resources) in the learning process, in which decorative writing does not appear.

- $\quad 81.8 \%$ of respondents do not consider decorative writing as important in the process of understanding a non-artistic text.

The answers to the open question why students perceive the meaning of photography in a non-artistic text as a factor influencing the comprehension of the text were processed by open coding (according to the methodological approach (Švaříček \& Šed'ová, 2010, p. 211) and classified into three categories:

1. Photographs as a factor contributing to the explanation of written information in a non-artistic text:

- photographs better explain the problem,

- photographs point to essential information and the meaning of the message,

- photographs explain the content of the text,

- photographs convey the content of the text.

\section{Photographs as a factor in grasping the broader context of the problem:}

- photographs enable to connect an idea with reality,

- photographs link information about the life of, e.g. a composer, with their appearance, behaviour,

\section{Photographs as an insignificant factor in understanding a} non-artistic text:

- photographs have no meaning in the comprehension of the non-artistic text

- photographs are not a significant factor in the process of understanding the text.

The answers to the open questions concerning the reasons student teachers like non-artistic texts, which include pictograms, have been processed by open coding and classified into three categories:

\section{Pictograms in a non-artistic text as a source of knowledge:}

- illustrate the situation described in the text,

- $\quad$ are a source of further knowledge.

\section{Pictograms as an essential factor in understanding a non-} artistic text:

- the text is more readable and understandable with the help of pictograms,

- pictograms help to comprehend the text,

- Pictograms help to combine text with image and imagination.

\section{Pictograms as factors of non-artistic text organisation:}

- $\quad$ pictograms help with orientation in non-artistic text,

- pictograms are helpful in the clarity of the text.

\section{Discussion}

We confirmed the effectiveness of diagnostic tools: a structured questionnaire and a semi-structured interview - by our research surveys of pupils of secondary technical schools and student teachers (who teach or want to teach at secondary technical schools). We also defined the factors that affect the level of reading and visual strategies of both groups of respondents in terms of working with images in the non-artistic text Questionnaire research confirmed that a non-artistic text, which includes illustrations, can be understood as a factor that activates students' critical thinking and reading strategies towards finding a context in the text. Image visualisations (e.g. illustrations, concept maps) in the non-artistic text are an influential factor influencing the comprehension of the text. The research did not confirm that students, who can appreciate non-traditionally processed non-artistic texts, prefer to read and learn interactive books, which at the same time do not encourage students to ask questions and search for essential information to understand the text. The results of interviews with student teachers interested in teaching at secondary technical schools confirmed that working with images (photographs, pictograms, illustrations) is one of the significant factors developing pupils' reading strategies. Decorative writing in the non-artistic text is more frequently perceived as a barrier (negative factor) in understanding the information read.

\section{Conclusions ( $\left(1^{\text {st }}\right.$ and $2^{\text {nd }}$ phases of research)}

\subsection{Conclusions from the $1^{\text {st }}$ phase of quantitatively oriented} research

The research was carried out by means of a questionnaire from the perspective of pupils of secondary technical colleges in the Moravian-Silesian Region of the Czech Republic.

Selected research results confirmed that:

- $\quad$ pupils more frequently prefer books for reading (learning), with the text accompanied by illustrations; in the course of reading they search for context. (H2)

- pupils who are influenced by the design of the book cover when choosing a book buy the book more frequently due to its nice (aesthetic) design. (H4)

The research did not confirm that:

- $\quad$ selecting a so-called interactive book encourages pupils to search for essential information in the text more frequently. (H1)

- choosing a book (non-artistic text) with illustrations encourages students to ask questions more frequently. (H3)

- the appreciation of non-traditional design of the book by pupils is the reason for more frequent selection of the socalled interactive book for reading or learning (H5)

\subsection{Conclusions from the $2^{\text {nd }}$ phase of research (pilotage)}

The research was carried out through a semi-structured interview with student teachers at the University of Ostrava (who already teach at secondary technical schools or desire to teach at this type of school in the future). The results of both research surveys demonstrated the need for current education with an emphasis on educating the reader, who can interpret images reflecting the multifaceted nature of the text and with an appeal to a functional understanding of the text.

The pilot research, through a semi-structured interview from the perspective of student teachers, showed that selected factors 
influencing the comprehension of a non-artistic text can be considered:

- photography as a factor contributing to the explanation of written information,

- pictograms as an important factor in understanding a nonartistic text

- pictograms as factors of organisation of the non-artistic text,

- the importance of decorative writing in the non-artistic text as a factor of clarity.

The research confirmed that most respondents:

- work with non-artistic texts, which include photographs,

- perceive the importance of photography in the process of understanding a non-artistic text,

- do not see the importance of decorative writing in the process of understanding non-artistic text.

- $\quad$ work with non-artistic texts, which include pictograms.

Developing reading and visual literacy is a lifelong need and a right of every human being. The reader and visually literate individual will successfully succeed in the labour market, as they are the bearer of mature receptivity and functional critical thinking. In the educational environment, emphasis must be placed on educating the reader, who can interpret images that reflect the multifaceted nature of not only artistic but also nonartistic text in a variety of teaching (e) sources and paper texts.

\section{Literature:}

1. Daňková, V. (2012). Uplatnění principu názornosti pri prípravě učebního textu z psychologie (Bakalářská práce). Zlín: Univerzita Tomáše Bati ve Zlíně, fakulta Humanitních studií. [Daňková, V. (2012). Application of the principle of illustration in the preparation of a psychology textbook (Bachelor's thesis). Zlín: Tomas Bata University in Zlín, Faculty of Humanities]

2. Dondis, D. A. (1984). A primer of visual literacy. 7. Vyd. New York, London: The MIT Press Cambridge.

3. Fleming, M. L. (1987). Designing Pictorial/Verbal Instruction: Some Speculative Extensions from Research to Practice. In Houghton H.A., Willows D.M. (eds). The Psychology of Illustration. Springer, New York, Vol. 1, 136-157. https://doi.org/10.1007/978-1-4612-4706-7_5.

4. Flood, J., Heath, S. B. \& Lapp, D. (2008). Thoughts on Visual Literacy. In: Handbook of Research on Teaching Literacy through the Communicative and Visual Arts. New York: Taylor and Francis Group.

5. Fulková, M. (2002). Když se řekne ...vizuální gramotnost. Výtvarná výchova, 42(4). ISSN 1210-3691. [Fulková, M. (2002). When it is said... visual literacy. Art Education, 42 (4). ISSN 1210-3691.]

6. Jacobson, R. \& Pomorska, K. (1993). Dialogy. Praha: Český spisovatel, 68. [Jacobson, R. \& Pomorska, K. (1993). Dialogues. Prague: Czech Writer, 68]

7. Klimeš, J. (2015). Hledání významu v umělecké narativní ilustraci. Brno: Masarykova univerzita, Filozofická fakulta. [Klimeš, J. (2015). Searching for meaning in artistic narrative illustration. Brno: Masaryk University, Faculty of Arts.]

8. Linhart, J. (1982). Základy psychologie učení. Praha: SPN. [Linhart, J. (1982). Introduction to psychology of learning. Praha: SPN.]

9. Mailaret, G. (1975). Zvuk a obraz jako nositelé informací ve výuce. In Modernizace metod výchovně-vzdělávací práce a moderní didaktická technika. Praha: SPN, 93-105. [Mailaret, G. (1975). Sound and image as carriers of information in teaching. In Modernisation of methods of educational work and modern didactic technique. Prague: SPN, 93-105]

10. Maňák, J. \& Švec, V. (2003). Výukové metody. Brno: Paido. ISBN 80-7315-039-5. [Maňák, J. \& Švec, V. (2003). Teaching methods. Brno: Paido. ISBN 80-7315-039-5.]

11. Mareš, J. (1995). Učení z obrazového materialu. Pedagogika, 45(4), 318-327. [Mareš, J. (1995). Learning from pictorial material. Pedagogy, 45 (4), 318-327.]
12. McLean-Thorne, D. R. (1994). Specific learning difficulties: An alternative perspective? School Psychology International, 15(1), 69-88. https://doi.org/10.1177/0143034394151005.

13. Molnár, J. \& Tláskal, J. (2012). Prostorová představivost nejen v matematice. Linguistica online. Available: http://ww w.phil.muni.cz/linguistica/art/molnar-tlaskal/mot-001.pdf [Molnár, J. \& Tláskal, J. (2012). Spatial imagination not only in mathematics. Linguistica online. Available: http://www.phil. muni.cz/linguistica/art/molnar-tlaskal/mot-001.pdf]

14. Park, Jie Y. (2012). A different kind of reading instruction: Using visualizing to bridge reading comprehension and critical literacy. Journal of Adolescent \& Adult Literacy, 55(7), 629-640. 15. Peterson, M. O. (2016). Schemes for integrating text and image in the science textbook: Effects on comprehension and situational interest. International Journal of Environmental \& Science Education, 11(6), 1365-1385.

16. Rankin, R. O. (1989). The development of an illustration design model. Educational Technology Research and Development, 37(2), 25-46.

17. Sternberg, R. J. (2009). Kognitivní psychologie. Praha: Portál, 640. [Sternberg, R.J. (2009). Cognitive psychology. Prague: Portal, 640.]

18. Trahorsch, P., Bláha, J. D. \& Janko, T. (2018). Analýza výzkumů vizuálií $\mathrm{v}$ učebnicích na př́kladu učebnic $\mathrm{s}$ geografickým obsahem. Pedagogická orientace, 28(1), 111-134. [Trahorsch, P., Blaha, J.D. \& Janko, T. (2018). Analysis of visual research in textbooks on the example of textbooks with geographical content. Pedagogical Orientation, 28 (1), 111134.]

19. Uhl Skřivanová, V., et al. (2014). Pedagogika umění uméní pedagogiky, aneb, prínos oboru výtvarná výchova ke všeobecnému vzdělávání. Ústí nad Labem: Univerzita Jana Evangelisty Purkyně. [Uhl Skrivanova, V., et al. (2014). Pedagogy of art - art of pedagogy, or, the contribution of the field of art education to general education. Ústí nad Labem: Jan Evangelista Purkyně University.]

\section{Primary Paper Section: A}

Secondary Paper Section: AM 